\title{
Powoływanie ławników do sądów pokoju i Sądu Okręgowego $w$ Eodzi $w$ pierwszych latach Polski międzywojennej
}

\author{
Abstract \\ Appointment of Lay Judges to the Courts of Peace and the District Court in \\ Łódź in the First Years of Interwar Poland
}

On July 18, 1917, the Provisional Council of State approved "Temporary Provisions on the Organization of the Judiciary in the Kingdom of Poland". These regulations granted the organization and functioning of the courts in the area of the newly created Kingdom of Poland, and was therefore binding in Łódź. It specified, inter alia, the rules for appointing lay judges to the courts of peace and regional courts. In Łódź, the implementation of the rules met numerous problems, related for example to the increase in the number of cases that were to be resolved with the participation of lay judges. There was also a problem with the initially low salary received by lay judges and the time needed by the City Council of Łódź to select candidates.

Keywords: jurors, court of peace, regional court, Second Polish Republic, Łódź

Słowa kluczowe: ławnicy, sąd pokoju, sąd okręgowy, II Rzeczpospolita, Łódź

\section{Wprowadzenie}

Aktem 5 XI 1916 r. państwa centralne proklamowały powstanie tworu państwowego, określonego mianem Królestwa Polskiego. Jeszcze 26 XI tego samego roku generał-gubernatorzy warszawski i lubelski wydali rozporządzenie (ogłoszone 6 XII), mocą którego została powołana Tymczasowa Rada Stanu. Organ ten miał charakter opinio- 
dawczy i doradczy, a do jego zdań należała współpraca przy tworzeniu organów nowo powstałego państwa ${ }^{1}$.

W skład Tymczasowej Rady Stanu wchodziło osiem departamentów, w tym m.in. Departament Sprawiedliwości. Został on powołany 23 I 1917 r., a działalność podjął tydzień później (30 I 1917 r.). Do jego zadań należało przede wszystkim przejęcie wymiaru sprawiedliwości. Prowadzone w tym zakresie prace legislacyjne doprowadziły do przygotowania projektu rozporządzenia „Przepisy tymczasowe o urządzeniu sądownictwa w Królestwie Polskim", zatwierdzonego przez Tymczasową Radę Stanu 18 VII tego samego roku³ . Akt ten obowiązywał na całym terytorium Królestwa, w tym również w Łodzi.

\section{Organizacja sądów pokoju i sądów okręgowych}

Zgodnie z „Przepisami tymczasowymi o urządzeniu sądownictwa w Królestwie Polskim” nowo tworzone sądy miały nosić miano Królewsko-Polskich i orzekać w imieniu Korony Polskiej. Należały do nich sądy pokoju, sądy okręgowe, sądy apelacyjne i Sąd Najwyższy $^{4}$. Oficjalne otwarcie sądów nastąpiło 1 IX 1917 r. $^{5}$

Sąd pokoju tworzyli sędziowie oraz ławnicy. Skład orzekający stanowili jeden sędzia pokoju (od którego nie wymagano wykształcenia prawniczego, ale praktyki sądowej lub adwokackiej) ${ }^{6}$ i dwóch ławników ${ }^{7}$. Rozpatrywał sprawy cywilne i karne mniejszej wagi ${ }^{8}$.

${ }^{1}$ Materniak-Pawłowska, Ustrój sądownictwa powszechnego, 17; Materniak-Pawłowska, „Departament Sprawiedliwości”, 249.

${ }^{2}$ Materniak-Pawłowska, Ustrój sadownictwa powszechnego, 18-19, 67, 74; Materniak-Pawłowska, „Departament Sprawiedliwości”, 250, 254, 256-259.

${ }^{3}$ Dziennik Urzędowy Departamentu Sprawiedliwości Tymczasowej Rady Stanu Królestwa Polskiego z 1917 r. nr 1; zob. też Wiśniewska, „Sądownictwo powszechne”, 176. Regulację uzupełniały przepisy „Tymczasowej instrukcji ogólnej dla sądów Królestwa Polskiego" zatwierdzonej przez dyrektora Departamentu 21 VIII 1917 r. (Dziennik Urzędowy Departamentu Sprawiedliwości Tymczasowej Rady Stanu Królestwa Polskiego z 1917 r. nr 2).

${ }^{4}$ Art. 4 rozporządzenia z 18 VII $1917 \mathrm{r}$.

${ }^{5}$ Materniak-Pawłowska, Ustrój sądownictwa powszechnego, 17, 20, 75; Materniak-Pawłowska, „Departament Sprawiedliwości”, 259, 264; Materniak-Pawłowska, „Sądy Królewsko-Polskie”, 87-88; Jastrzębski, „O stu latach”, 7.

${ }^{6}$ Ryszka, Historia państwa, 16; Materniak-Pawłowska, Ustrój sądownictwa powszechnego, 76.

${ }^{7}$ Art. 5 rozporządzenia z 18 VII $1917 \mathrm{r}$.

${ }^{8}$ Płaza, Historia prawa, cz. III, 620. Właściwość rzeczową sądów pokoju (w sprawach karnych) regulowały „Przepisy przechodnie do ustawy postępowania karnego” z 18 VII 1917 r. (Dziennik Urzędowy Departamentu Sprawiedliwości Tymczasowej Rady Stanu Królestwa Polskiego z 1917 r. nr 1): art. 2 „Rozpoznaniu sądów pokoju w sprawach karnych ulegają:

1) wszelkie przestępstwa zagrożone w częściach: $6,7,9,10,11,12,13,14,16,17,18,19,20,25$, 26, 27, 28, 29, 30 i 31 kodeksu karnego rosyjskiego z r. 1903 oraz w innych przepisach karnych karą osadzenia w areszcie lub karą grzywny, oddzielnie lub łącznie z karami dodatkowymi;

2) przestępstwa zagrożone karą w art. 474, 475, 531, 617 kodeksu karnego i wszystkie przestępstwa, objęte częścią 36-tą tegoż kodeksu;

3) przestępstwa zagrożone karą w art. 574 ust. 1, 581 cz.1, 591 cz. 1 i 2, 592, jeżeli wartość przywłaszczonego przedmiotu nie przekracza marek polskich 1000, oraz w art. 574 cz. 3 i 4, 581 cz. 4, 591 cz. 3 tegoż kodeksu; 
W zakresie lokalizacji sądów tego szczebla Tymczasowa Rada Stanu wydała 18 VII rozporządzenie „Przepisy tymczasowe o dyzlokacji sądów Królewsko-Polskich”9. Zgodnie $\mathrm{z}$ art. 1 tego aktu sądy pokoju miały siedziby dotychczasowych sądów pokoju i sądów gminnych, zachowały również ich właściwość miejscową. Ewentualne zmiany w tym zakresie mogła przeprowadzić Tymczasowa Rada Stanu. Łącznie powołano 437 sądów tego szczebla ${ }^{10}$.

W skład sądu okręgowego wchodzili: prezes, wiceprezesi, sędziowie okręgowi i śledczy oraz ławnicy. Komplet orzekający w sprawach cywilnych stanowiło trzech sędziów, zaś w sprawach handlowych oraz w sprawach karnych - jeden sędzia i dwóch ławników ${ }^{11}$. Sąd okręgowy w I instancji rozpatrywał wszystkie sprawy z wyjątkiem tych,

4) ukrycie lub nabycie, zagrożone karą przez ustęp 1 art. 616 kodeksu karnego, gdy przedmioty cudze zdobyte zostały za pomocą występku i gdy czyn, którego dotyczy ukrycie lub nabycie, należy do właściwości sądów pokoju.

Nie ulegają rozpoznaniu sądów pokoju:

1) sprawy, w których kara dodatkowa polega na pozbawieniu prawa wykonywania zawodu, procederu lub rzemiosła lub w ogóle jakiegokolwiek prawa specjalnego;

2) sprawy, w których wytyczono powództwo cywilne w sumie, przewyższającej marek polskich 1000 ;

3) sprawy, w których wartość przedmiotów, ulegających konfiskacie, albo robót, mających być wykonanymi z mocy wyroku, przenosi marek polskich 1000".

Natomiast właściwość rzeczową sądów pokoju (w sprawach cywilnych) regulowały „Przepisy przechodnie do ustawy postępowania cywilnego także z 18 VII 1917 r. (Dziennik Urzędowy Departamentu Sprawiedliwości Tymczasowej Rady Stanu Królestwa Polskiego z 1917 r. nr 1). Art. 2 tego aktu stanowił: „Rozpoznaniu sądów pokoju ulegają:

1. w sprawach cywilnych, mających za przedmiot spory majątkowo-prawne:

a) sprawy, których przedmiot nie przenosi tysiąca marek polskich;

b) sprawy o przywrócenie utraconego lub zakłóconego posiadania oraz używania służebności, jeżeli od chwili utraty lub zakłócenia nie upłynął rok jeden;

c) żądanie zabezpieczenia dowodów, w sprawach jeszcze nie wytoczonych, bez ograniczenia sumy, jeżeli przedsięwzięcie środków zabezpieczenia dowodów nie cierpi zwłoki (art. 824 ust. pos. cyw.);

d) sprawy działowe, dotyczące drobnej własności ziemskiej poza obrębem miast, o ile majątek, działom ulegający, nie przenosi jednej włóki (30 polskich morgów) ziemi i nie ma tam innych budynków, oprócz niezbędnych w zwykłym gospodarstwie, a wartość ruchomości nie przenosi trzech tysięcy marek polskich;

2. wszelkie sprawy sądownictwa niespornego, które dotychczas należały do sądów pokoju i gminnych.

Rozpoznaniu sądów pokoju, bez względu na wartość przedmiotu sporu nie ulegają:

a) sprawy o własność nieruchomą i o prawa rzeczowe, dotyczące nieruchomości, z wyjątkiem wymienionych w poprzednim ustępie (art. 2, ust. 1, punkt d);

b) spory o przywileje, wynalazki i prawa autorskie;

c) sprawy, w których biorą udział instytucje skarbowe (z wyjątkiem spraw o przywrócenie utraconego lub zakłóconego posiadania)".

${ }_{9}$ Dziennik Urzędowy Departamentu Sprawiedliwości Tymczasowej Rady Stanu Królestwa Polskiego z 1917 r. nr 1.

${ }^{10}$ Materniak-Pawłowska, „Struktura polskich sądów powszechnych”, 277; Materniak-Pawłowska, Ustrój sqdownictwa powszechnego, 80; Materniak-Pawłowska, „Departament Sprawiedliwości”, 265; Materniak-Pawłowska, „Sądy Królewsko-Polskie”, 96.

${ }^{11}$ Art. 6 rozporządzenia z 18 VII 1917 r. 
które należały do właściwości sądu pokoju, a w drugiej instancji - środki odwoławcze od orzeczeń tych sądów ${ }^{12}$.

Art. 6 ust. 7 rozporządzenia zastrzegał, że odrębny skład orzekający w sprawach handlowych miał być powoływany tylko w miejscowościach wskazanych przez Departament Sprawiedliwości Tymczasowej Rady Stanu. Natomiast w innych miejscowościach sprawy miał rozstrzygać skład właściwy dla spraw cywilnych.

Na podstawie zarządzenia Tymczasowej Rady Stanu z 7 VII 1917 r. „Dyzlokacja sądów Królewsko-Polskich" utworzono 15 sądów okręgowych w następujących miastach: Kielce, Lublin, Piotrków, Radom, Częstochowa, Kalisz, Łomża, Łowicz, Łódź, Mława, Płock, Siedlce, Sosnowiec, Warszawa i Włocławek ${ }^{13}$. Przy czym okręg łódzki obejmował powiaty: łódzki, brzeziński, łęczycki oraz część powiatu łaskiego znajdującą się pod okupacją niemiecką. Następnie w 1918 r. utworzono kolejny sąd okręgowy z siedzibą w Zamościu ${ }^{14}$.

W myśl rozporządzenia z 18 VII 1917 r. „Przepisy tymczasowe o dyzlokacji sądów Królewsko-Polskich"15 siedziby i okręgi sądów tego szczebla mogła określać Tymczasowa Rada Stanu.

Wraz z odzyskaniem niepodległości przez państwo polskie sądy Królewsko-Polskie przestały funkcjonować i uległy przekształceniu w sądy polskie, które jednak podlegały dotychczasowym przepisom ${ }^{16}$.

12 Płaza, Historia prawa. Cz. III, 620; Materniak-Pawłowska, „Sądy Królewsko-Polskie”, 93.

Właściwość rzeczową sądów okręgowych regulowały „Przepisy przechodnie do ustawy postępowania karnego z 18 VII 1917 r. (Dziennik Urzędowy Departamentu Sprawiedliwości Tymczasowej Rady Stanu Królestwa Polskiego z 1917 r. nr 1): art. 3 „Rozpoznaniu sądów okręgowych ulegają następujące sprawy karne:

1) w pierwszej instancji: wszelkie przestępstwa, dla których nie są właściwe sądy pokoju;

2) w drugiej instancji: skargi apelacyjne i incydentalne na wyroki i decyzje sądów pokoju.

Apelacja nie służy od wyroków, skazujących najwyżej na 3 dni aresztu lub 50 marek polskich kary pieniężnej”.

Natomiast właściwość rzeczową sądów okręgowych (w sprawach cywilnych) regulowały „Przepisy przechodnie do ustawy postępowania cywilnego także z 18 VII 1917 r. (Dziennik Urzędowy Departamentu Sprawiedliwości Tymczasowej Rady Stanu Królestwa Polskiego z 1917 r. nr ). Art. 3 tego aktu stanowił: „Rozpoznaniu sądów okręgowych ulegają następujące sprawy cywilne:

1. w pierwszej instancji: wszelkie sprawy zarówno sporne, jak i sądownictwa niespornego, dla których nie są właściwe sądy pokoju lub sądy specjalne (konsystorskie), jak również sprawy o zarządzanie nadzoru celem uniknięcia upadłości, tudzież zgłoszenia o wciągnięcie do rejestru firmowego (ksiąg jawności handlowej) i w ogóle wszelkie funkcje, które na mocy rozporządzeń Generał-Gubernatora Warszawskiego ulegały rozpoznaniu c.n. sądów okręgowych.

2. w drugiej instancji: skargi apelacyjne i incydentalne na wyroki i decyzje sądów pokoju oraz wydziałów hipotecznych przy tychże sądach.

Apelacja nie służy w sprawach, w których suma sporu nie przenosi stu marek, z wyjątkiem spraw o należność za pracę lub służbę".

${ }_{13}$ Dziennik Urzędowy Departamentu Sprawiedliwości Tymczasowej Rady Stanu Królestwa Polskiego z 1917 r. nr 1. Materniak-Pawłowska, „Struktura polskich sądów powszechnych”, 277. Materniak-Pawłowska, strój sądownictwa powszechnego, 80; Materniak-Pawłowska, „Departament Sprawiedliwości”, 265. Materniak-Pawłowska, „Sądy Królewsko-Polskie”, 92, 96.

${ }^{14}$ Materniak-Pawłowska, „Struktura polskich sądów powszechnych”, 277. Materniak-Pawłowska, „Sądy Królewsko-Polskie”, 96-97.

${ }_{15}$ Dziennik Urzędowy Departamentu Sprawiedliwości Tymczasowej Rady Stanu Królestwa Polskiego z 1917 r. nr 1.

${ }^{16}$ Materniak-Pawłowska, „Sądy Królewsko-Polskie”, 105. 


\section{Zasady powoływania ławników a praktyka łódzka}

Reguły dotyczące powoływania ławników określał art. 24 ust. 1-3 rozporządzenia z 18 VII 1917 r. Nie odnosiły się one jednak do pierwszego przydziału, którego zasady wyznaczał ust. 4 powołanego wyżej przepisu. Zadanie wskazania pierwszych ławników powierzał on Dyrektorowi Departamentu Sprawiedliwości. Dyrektor nie był ograniczony żadnymi kandydaturami i decydował samodzielnie. Nie mógł jednak powołać ich na okres dłuższy niż sześć miesięcy, licząc od dnia rozpoczęcia urzędowania danego sądu.

Pierwsi ławnicy królewsko-polskich sądów pokoju (dziewięciu okręgów) i Królewsko-Polskiego Sądu Okręgowego w Łodzi (dalej: KPSOwŁ) zostali powołani na okres sześciu miesięcy. Ich kadencja trwała od 1 IX 1917 r. do 1 III 1918 r. ${ }^{17}$ Nie ma informacji na temat zawodu ławników wchodzących w skład sądu okręgowego, natomiast osoby powołane do sądów pokoju reprezentowały następujące zawody czy funkcje:

Tabela 1.

\begin{tabular}{|l|l|l|}
\hline \multicolumn{1}{|c|}{ Lp. } & \multicolumn{1}{|c|}{ Zawód/funkcja } & \multicolumn{1}{c|}{ Liczba osób } \\
\hline 1 & Właściciel domu & 23 \\
\hline 2 & Kupiec & 14 \\
\hline 3 & Fabrykant & 13 \\
\hline 4 & Rzemieślnik & 11 \\
\hline 5 & Inżynier & 7 (1 d. fabryki i 1 d. tramwajów) \\
\hline 6 & Dyrektor & 4 \\
\hline 7 & Drogista & 3 \\
\hline 8 & Właściciel apteki & 3 \\
\hline 9 & Handlowiec & 3 \\
\hline 10 & Buchalter & 2 \\
\hline 11 & Urzędnik & 1 \\
\hline 12 & Właściciel piekarni & 1 \\
\hline 13 & Lawnik magistratu & 1 \\
\hline 14 & Majster fabryczny & 1 \\
\hline 15 & Majster tkacki & 1 \\
\hline 16 & Majster ślusarski & 1 \\
\hline 17 & Majster blacharski & 1 \\
\hline 18 & Majster farbiarski & 1 \\
\hline 19 & Administrator & 1 \\
\hline 20 & Prokurent & 1 \\
\hline 21 & Bankowiec & 14 \\
\hline 22 & Brak danych & \\
\hline & & \\
\hline
\end{tabular}

Źródło: opracowanie własne na podstawie pisma Prezesa KPSOwŁ nr 781 z 16 II 1918 r.; APŁ, Akta miasta Łodzi. Rada Miejska, sygn. 13104 Sprawa wyboru ławników (1917-1918), mikrofilm L-10980, 10-17

17 Odezwa Prezesa Królewsko-Polskiego Sądu Okręgowego w Łodzi z 7 I 1918 r.; APŁ, AMŁ 13104, 3. 
Należy podkreślić, że wśród ławników nie było kobiet. Nie zmieniło się to także w kolejnych latach, a stanowiska ławników w całym badanych okresie zajmowali wyłącznie mężczyźni.

Kolejni ławnicy mieli już być powoływani zgodnie z art. 24 ust. 1-3 rozporządzenia z 18 VII 1917 r. W świetle tego przepisu kandydat na ławnika musiał spełniać następujące kryteria: legitymować się obywatelstwem polskim ${ }^{18}$ i nieposzlakowaną opinią. Ponadto powinien się wykazać „dostateczną” znajomością języka polskiego zarówno w mowie, jak i w piśmie. Ten ostatni wymóg mógł być trudny do spełnienia, zwłaszcza biorąc pod uwagę problem analfabetyzmu ludności. W przypadku kandydatów na ławników sądów pokoju wystarczające było spełnienie tych wymogów. Osoby ubiegające się o stanowiska w sądach wyższych musiały jednak posiadać co najmniej wykształcenie średnie. Nie wymagano od nich natomiast wykształcenia prawniczego ${ }^{19}$.

Listę, zawierającą podwójną liczbę kandydatów, formułowały wskazane w rozporządzeniu organy: sejmiki powiatowe, rady miejskie, a w miejscowościach, w których takie nie funkcjonowały - obywatelskie komitety ratunkowe lub inne, odpowiadające im instytucje obywatelskie. Przy czym ławnicy powoływani do rozstrzygania w sprawach handlowych byli wybierani przez kupiectwo ,stosownie do przepisów obowiązujących przy wyborze sędziów handlowych" i nosili miano sędziów handlowych.

Ławników powoływali odpowiednio: do sądu pokoju - prezes sądu okręgowego, w którego okręgu znajdował się sąd pokoju, a do sądu okręgowego - prezes sądu apelacyjnego. Osoby wskazane na listach, które nie zostały mianowane na stanowiska ławników, uznawano za ich zastępców.

Kadencja ławników wynosiła rok, a osoby obejmując urząd musiały złożyć uroczyste przyrzeczenie według roty sformułowanej w art. 14 rozporządzenia.

7 I 1918 r. Kazimierz Rossman, prezes KPSOw£, zwrócił się do Rady Miejskiej z prośbą o sporządzenie dwóch list kandydatów na ławników, odrębnie dla sądu okręgowego i dla sądów pokoju. Do składu pierwszego z nich miało zostać mianowanych 30 ławników, do sądów pokoju zaś - 100. Listy musiały jednak zawierać podwójną liczbę kandydatów. Uprzedzał, że osoby, które nie zostałyby mianowane na stanowiska ławników, pozostawałyby w charakterze ich zastępców ${ }^{20}$.

W odpowiedzi na odezwę przewodniczący Rady Miejskiej skierował do Komisji Pojednawczo-Wyborczej wniosek o wskazanie kandydatów na członków komisji, która miałaby się zająć ułożeniem list ławników. Komisja ta miała się składać maksymalnie z 12 osób. Ustalenie jej składu zostało zaplanowane na posiedzenie Rady Miejskiej 13 II $1918 r^{21}$

W związku z opieszałością Rady Miejskiej prezes KPSOwŁ 12 II wystosował kolejne pismo w sprawie wyboru kandydatów na ławników, zwracając uwagę na szybki koniec kadencji ${ }^{22}$. W odpowiedzi na nie przewodniczący Rady wskazał, że:

[...] sprawa zatwierdzenia listy ławników do Królewsko-Polskich Sądów Okręgowego i Pokoju, ułożeniem której to listy zajmuje się Komisja, specjalnie w tym celu wyłoniona, załatwiona będzie

\footnotetext{
${ }^{18} \mathrm{Z}$ art. 13 wynika, że chodziło o obywatelstwo Królestwa Polskiego.

19 Materniak-Pawłowska, „Zawód sędziego”, 65.

20 Odezwa Prezesa KPSOwŁ z 7 I 1918 r.; APŁ, AMŁ 13104, 3.

21 Pismo Prezesa Rady Miejskiej z 5 II 1918 r. nr 25/18; ibid., 4.

22 Pismo Prezesa KPSOwŁ nr 719 z 12 II 1918 r.; ibid., 5.
} 
na posiedzeniu Rady Miejskiej w dniu 28 b.m., wobec czego lista ta zostanie przesłana J. Panu dopiero w końcu przyszłego tygodnia, t.j. około 2 marca r.b. ${ }^{23}$

Termin na zgłaszanie kandydatów komisja oznaczyła ostatecznie na 5 marca $1918 \mathrm{r}^{24}$ Prośba o wskazanie kandydatów została przesłana do następujących podmiotów: Stowarzyszenia Handlowców Polskich ${ }^{25}$, Komisji Międzyzwiązkowej Stowarzyszeń Robotników Chrześcijańskich, Urzędu Starszych Zgromadzenia Kupców Miasta Łodzi, Komitetu Giełdowego Łódzkiego, Resursy Rzemieślniczej Chrześcijańskiej, Klubu Rzemieślniczego, Rady Związków i Stowarzyszeń Robotniczych, Sekcji Przemysłu Włóknistego Okręgu Łódzkiego, Komisji Międzyzwiązkowej Rady Związków i Stowarzyszeń Robotniczych, Stowarzyszenia Właścicieli Nieruchomości Miasta Łodzi oraz II Stowarzyszenia Właścicieli Nieruchomości Miasta Łodzi ${ }^{26}$, Stowarzyszenia Zawodowego „Praca”, Stowarzyszenia Pracowników Handlowych Chrześcijan, Stowarzyszenia Komiwojażerów, Stowarzyszenia Drobnych Kupców i Przemysłowców ${ }^{27}$, a także do Stowarzyszenia Techników w Łodzi²8.

Kandydatów na ławników spośród swoich członków ostatecznie wskazali: Stowarzyszenie Wzajemnej Pomocy Pracowników Handlowych Miasta Łodzi (20 osób $)^{29}$, Resursa Rzemieślnicza Chrześcijańska(36 osób) ${ }^{30}$, II Stowarzyszenie Właścicieli Nieruchomości Miasta Łodzi (12 osób) ${ }^{31}$, Stowarzyszenie Właścicieli Nieruchomości Miasta Łodzi (48 osób) ${ }^{32}$, Klub Rzemieślniczy (22 osoby) $)^{33}$, Stowarzyszenie Wzajemnej Pomocy Pracujących w Przemyśle i Handlu Miasta Łodzi (tzw. Stowarzyszenie Handlowców Polskich) (50 osób) ${ }^{34}$, Sekcja Przemysłu Włóknistego Okręgu Łódzkiego (14 osób) $)^{35}$, Urząd Starszych Zgromadzenia Kupców m. Łodzi (58 osób) ${ }^{36}$, Stowarzyszenie Robotników Chrześcijańskich (13 osób) ${ }^{37}$, Stowarzyszenie Zawodowe „Praca” $(31 \text { osób })^{38}$, Stowarzyszenie Właścicieli Składów Aptecznych „Drogista” (7 osób) ${ }^{39}$, Komisja Międzyzwiązkowa Stowarzyszeń Robotników Chrześcijańskich (5 osób, jednak już wcześniej odrębnie wskazały kandydatów wchodzące w skład tej komisji: Stowarzyszenie Zawodowe „Praca” i Stowarzyszenie Robotników Chrześcijańskich) ${ }^{40}$,

${ }^{23}$ Pismo z 14 II 1918 r.; ibid., 6.

24 Protokół z posiedzenia Komisji powołanej do ułożenia listy ławników do Sądu Okręgowego i Sądów Pokoju z 26 II 1918 r.; ibid., 33-34.

${ }_{25}$ Pismo nr 221/18 z 23 II 1918 r.; ibid., 29.

26 Ibid., 9.

27 Protokół z posiedzenia Komisji powołanej do ułożenia listy ławników do Sądu Okręgowego i Sądów Pokoju z 26 II 1918 r.; APŁ, AMŁ 13104, 33.

28 Pismo z 27 II 1918 r.; ibid., 36.

29 Pismo z 15 II 1918 r.; ibid., 18-19.

30 Pismo z 20 II 1918 r.; ibid., 21-22.

31 Ibid., 23.

32 Pismo z 21 II 1918 r.; APŁ, AMŁ 13104, 24-25.

33 Ibid., 26-27.

34 Pismo z 26 II 1918 r.; APŁ, AMŁ 13104, 30

35 Ibid., 35.

36 Pismo nr 33 z 25 II 1918 r.; APŁ, AMŁ 13104, 38-39.

37 Pismo z 27 II 1918 r.; ibid., 54.

38 Ibid., 55-57.

39 Pismo z 1 III 1918 r.; APŁ, AMŁ 13104, 58.

40 Pismo z 2 III 1918 r.; APŁ, AMŁ 13104, 59. 
Stowarzyszenie Komiwojażerów (14 osób) ${ }^{41}$, Stowarzyszenie Polskich Kupców i Przemysłowców Chrześcijan w Łodzi (86 osób) ${ }^{42}$, Stowarzyszenie Techników w Łodzi (27 osób) $)^{43}$, Stowarzyszenie Drobnych Kupców i Przemysłowców Polskich w Łodzi (8 osób $)^{44}$. Po terminie, bo dopiero 7 III, swoich kandydatów wskazało Stowarzyszenie Majstrów Fabrycznych gub. Piotrkowskiej"5, a 14 III - Towarzystwo Literatów i Dziennikarzy Polskich ${ }^{46}$.

Przedstawienia kandydatów spośród swoich członków odmówiły natomiast Rada Związków i Stowarzyszeń Robotniczych ${ }^{47}$ oraz Komisja Międzyzwiązkowa Związków Zawodowych w Łodzi ${ }^{48}$.

W kolejnych latach poza stowarzyszeniami i związkami zawodowymi kandydatów na ławników zgłaszały także poszczególne frakcje Rady Miejskiej. Na przykład w wyborach, które odbyły się na początku 1924 r., kandydatów wskazały Koło Narodowe, Chrześcijańska Demokracja, frakcja żydowska, frakcja żydowska ortodoksyjna i NPP49.

W trakcie wyborów odbywających się w 1918 r. listy kandydatów na ławników miała sporządzić komisja powołana przez Radę Miejską specjalnie w tym celu. W późniejszym zaś okresie zadanie to powierzano Konwentowi Seniorów Rady Miejskiej ${ }^{50}$.

Komisja rozpoczęła pracę nad wyłonieniem kandydatów 6 III 1918 r. Wzięła pod uwagę listy przedstawione przez 15 podmiotów. Jednocześnie ograniczyła możliwość wyboru ławników, nie dopuszczając osób, które wówczas pełniły takie funkcje, oraz osób udzielających porad prawnych, a także osób, które „,[zajmowały] inne społeczne stanowiska". W trakcie prac pojawiła się również koncepcja niedopuszczenia urzędników magistratu oraz członków Rady Miejskiej. Nie znalazła ona jednak poparcia ${ }^{51}$. Wynika z tego, że komisja przyjęła dodatkowe kryteria, nieuregulowane w rozporządzeniu.

${ }^{41}$ Pismo z 1 III 1918 r.; ibid., 60.

42 Pismo z 4 III 1918 r.; ibid., 63-64.

${ }^{43}$ Ibid., 65-66.

${ }^{44}$ Pismo z 3 III 1918 r.; APŁ, AMŁ 13104, 67.

${ }^{45}$ Pismo z 7 III 1918 r.; ibid., 70.

46 Pismo z 14 III 1918 r.; ibid., 72.

47 „Potwierdzając niniejszym odbiór listów Szan. Panów z dn. 16 i 27 lutego 1918 r. w sprawie wyboru ławników do Królewsko-Polskich Sądów Okręgowego i Pokoju, uprzejmie komunikujemy, że ze względów zasadniczych, w wspomnianych wyżej wyborach, udziału nie weźmiemy"; Pismo nr 294/4-18 z 2 III 1918 r.; ibid., 61.

${ }^{48}$ „W odpowiedzi na listy Szan. Panów z dn. 27 i 16 ub.m. w sprawie wyboru ławników do Królewsko-Polskich Sądów Okręgowego i Pokoju uprzejmie komunikujemy, że ze względów zasadniczych udziału w wyborach ławników nie bierzemy"; ibid., 62.

49 Wyciąg z protokołu posiedzenia Konwentu Seniorów z 11 III 1924 r.; APŁ, AMŁ 13105, 326-327.

${ }^{50}$ Adnotacja na piśmie nr 203 z 27 III 1919 r.; APŁ, AMŁ 13105, 2; Pismo nr 1209/20 z 10 IX 1920 r.; ibid., 117.

${ }^{51}$ Protokół z posiedzenia Komisji powołanej do ułożenia listy ławników do Sądu Okręgowego i Sądów Pokoju z 6 III 1918 r.; APŁ, AMŁ 13104, 68-69. 
Listy kandydatów na ławników KPSOwŁ i sądów pokoju zostały ostatecznie sporządzone 18 III 1918 r. i przesłane Prezydium Rady Miejskiej52. Rada zatwierdziła je dopiero na posiedzeniu $24 \mathrm{IV}^{53}$.

Problem związany z przedłużaniem się czasu formułowania list wystąpił także w kolejnym roku. Prezes Sądu Okręgowego w Łodzi (dalej: SOwŁ) wystosował odezwę do Rady Miejskiej w tej sprawie 27 III $1919 \mathrm{r}^{54} \mathrm{~W}$ następnych pismach ponaglał Radę ${ }^{55}$, a także wskazywał, że kadencja dotychczasowych ławników już się zakończyła ${ }^{56}$. Rada Miejska zatwierdziła przez aklamację listę kandydatów do Sądu Okręgowego dopiero 17 VI 1919 r. ${ }^{57}$, a do sądów pokoju - następnego dnia ${ }^{58}$.

W późniejszym okresie sytuacja się jednak nie powtórzyła (np. 19 VIII 1920 r. prezes SOwŁ wydał odezwę w sprawie wskazania przez Radę Miejską 120 kandydatów na ławników SOwE ${ }^{59}$, a Rada podjęła uchwałę 7 IX 1920 r. $^{60}$ ).

Zasady powoływania ławników uległy zmianie w drodze Ustawy z dnia 18 marca 1921 r. w przedmiocie niektórych zmian $w$ przepisach tymczasowych o urzadzeniu sadownictwa $w$ b. Królestwie Polskiem ${ }^{61}$, która weszła w życie $6 \mathrm{~V}$ tego samego roku, i były związane z ograniczeniem ich roli. Przede wszystkim zmiana dotyczyła udziału ławników w pracach sądów pokoju. Zasadniczo sądy te miały orzekać w składzie jednego sędziego i dwóch ławników. Jednak w miastach powiatowych lub innych, liczących ponad 10 tysięcy mieszkańców, sędzia pokoju (o ile posiadał wykształcenie prawnicze) orzekał jednoosobowo. W przypadku braku sędziego pokoju (do czasu powołania jego specjalnego zastępcy przez ministra sprawiedliwości) mógł go zastąpić upoważniony ławnik, przy czym nie mógł on rozstrzygać spraw jednoosobowo ${ }^{62}$.

Ustawa ograniczyła rolę ławników również w sądach okręgowych. Od tej pory ławnicy brali udział tylko w kompletach rozstrzygających sprawy handlowe, dla których właściwy był skład orzekający w postaci jednego sędziego i dwóch ławników. Jednak nieobecnego ławnika mógł zastąpić sędzia ${ }^{63}$.

Zmianie uległ katalog podmiotów uprawnionych do sporządzenia listy kandydatów na ławników. W przypadku sądów pokoju mogły to robić zgromadzenia gminne i rady miejskie, a w miejscowościach, w których takich organów nie było, kandydatów miały wskazywać instytucje wyznaczone przez ministra sprawiedliwości. Wydłużona została także do trzech lat kadencja ławników. Zastrzeżono również, że osoba ustępująca

${ }^{52}$ Protokół z posiedzenia Komisji powołanej do ułożenia listy ławników do Sądu Okręgowego i Sądów Pokoju z 18 III 1918 r. APŁ, AMŁ 13104, 83. 95-96.

53 Pismo do Prezesa Królewsko-Polskiego Sądu Okręgowego w Łodzi z 25 IV 1918 r.; APŁ, AMŁ 13104,

${ }^{54}$ Odezwa nr 203 z 27 III 1919 r.; APŁ, AMŁ 13105, 1.

${ }_{55}$ Pismo z 6 V 1919 r.; ibid., 6.

${ }^{56}$ Pismo z 5 VI 1919 r.; ibid., 40.

${ }^{57}$ Adnotacja na liście kandydatów na ławników; ibid., 86.

58 Ibid., 87.

59 Odezwa Prezesa Sądu Okręgowego w Łodzi nr 7585/20 z 19 VIII 1920 r.; APŁ, AMŁ 13105, 116.

${ }^{60}$ Pismo nr 1209/20 z 10 IX 1920 r.; ibid., 117.

${ }^{61}$ Dz.U. 1921, nr 30 poz. 172; Gołąb, Organizacja sądów powszechnych, 45; Materniak-Pawłowska, Ustrój sadownictwa powszechnego, 75; Płaza, Historia prawa w Polsce. Cz. III, 619-620.

${ }_{62}$ Znowelizowany mocą tej ustawy art. 5 przepisów tymczasowych o urządzeniu sądownictwa w b. Królestwie Polskiem.

${ }^{63}$ Znowelizowany art. 6 przepisów tymczasowych o urządzeniu sądownictwa w b. Królestwie Polskiem. 
z tego stanowiska miała je piastować aż do momentu powołania następcy ${ }^{64}$. W przypadku Łodzi, w której kandydatów na ławników już uprzednio wskazywała Rada Miejska, nic się nie zmieniło.

\section{Problemy kadrowe i płacowe}

Łódzkie sądy pokoju borykały się z problemami kadrowymi związanymi z obsadą stanowisk ławniczych. Informował o tym prezes SOwŁ w odezwie z 18 II 1920 r., skierowanej do magistratu. Pisał on:

Z nadesłanej mi przez Radę Miejską w dniu 28 lipca 1919 r. za Nr 517/19 listy kandydatów na ławników dla Sądów Pokoju w Łodzi wyznaczyłem wszystkie wymienione w liście osoby. Ponieważ z liczby osób wskazanych poważna ilość zrzekła się mandatów, gdyż po większej części są to robotnicy fabryczni i rzemieślnicy, którzy wobec uruchomienia przemysłu powrócili do pracy i sprawowanie obowiązków ławników jest dla nich uciążliwe, proszę Magistrat o nadesłanie mi nowej listy kandydatów, zawierających 120 nazwisk $^{65}$.

Konwent Seniorów wskazał kandydatów na ławników 20 IV 1920 r. ${ }^{66}$, a dzień później Rada Miejska ich zatwierdziła ${ }^{67}$.

Problemy kadrowe nie zostały jednak rozwiązane i 13 X 1920 r. prezes SOw屯 ponownie zwrócił się do Rady Miejskiej z apelem o wskazanie kolejnych 40 kandydatów na ławników. Uzasadniał ten problem nieodnalezieniem części osób wskazanych uprzednio przez Radę Miejską ${ }^{68}$.

Poza tym sądy pokoju wskazywały na zbyt małą liczbę ławników w stosunku do liczby toczących się spraw. W związku z tym wnioskowały o zwiększenie liczby ławników. Z taką prośbą zwrócił się do prezesa SOwŁ Sąd Pokoju VI Okręgu 8 X 1920 r., wskazując, że „liczba 15 ławników, przy częstem wymawianiu się tych ostatnich brakiem czasu, nie wystarcza na 5-6 sesji tygodniowo" ${ }^{69}$.

Problem narastał, o czym informował prezes SOwE:

Ze względu na nawał spraw w Sądach pokoju m. Łodzi w niektórych Sądach będą zdwojone komplety wyrokujące, dlatego zachodzi konieczność powiększenia liczby ławników. Z mocy art. 1 i 24 Ustawy z dnia 18.III.21 (Dziennik Ustaw Nr 30 poz. 172) proszę Radę Miejską o jak najszybsze nadesłanie mi list kandydatów na 50 osób ławników do Sądów pokoju w Łodzi ${ }^{70}$.

Problemy kadrowe były także związane z niewielką wysokością wynagrodzenia przysługującego ławnikom, a wynoszącą zaledwie 5 marek polskich za posiedzenie ${ }^{71}$. Na ten problem zwróciła uwagę Komisja do Spraw Ogólnych Rady Miejskiej w Łodzi

${ }^{64}$ Znowelizowany art. 24 przepisów tymczasowych o urządzeniu sądownictwa w b. Królestwie Polskiem.

65 Odpis odezwy Prezesa Sądu Okręgowego w Łodzi nr 1781 z 18 II 1920 r.; APŁ, AMŁ 13105, 105.

${ }^{66}$ Wyciąg z protokołu posiedzenia Konwentu Seniorów z 20 IV 1920 r.; ibid., 110.

${ }^{67}$ Adnotacja na Wyciągu z protokołu posiedzenia Konwentu Seniorów z 20 IV 1920 r.; ibid., 115.

68 Odpis odezwy Prezesa Sądu Okręgowego w Łodzi nr 11300/20 z 13 X 1920 r.; ibid., 130.

69 Odpis odezwy Prezesa Sądu Okręgowego w Łodzi nr 11390/20 z 1 XI 1920 r.; ibid., 136.

70 Odezwa Prezesa Sądu Okręgowego w Łodzi nr 4532/22 z 28 VIII 1922 r.; ibid., 300.

71 Odpis odezwy Prezesa Sądu Okręgowego w Łodzi nr 3080 z 28 III 1920 r.; ibid., 105. 
na posiedzeniu, które odbyło się 17 I 1921 r. Wskazała ona, że wysokość wynagrodzenia zmusza niektóre osoby, zwłaszcza robotników, do unikania pełnienia obowiązków ławników. Zdaniem komisji konieczność udziału w posiedzeniach sądowych pozbawiała robotnika znacznej części wynagrodzenia otrzymywanego w miejscu pracy. Jednocześnie komisja podkreślała konieczność pełnienia funkcji ławników również przez te osoby, ze względu na potrzebę obrony interesów tejże grupy społecznej. W związku z tym postanowiła zwrócić się do rządu z wnioskiem o podniesienie stawki dla ławnika do wysokości dziennego wynagrodzenia otrzymywanego przez niewykwalifikowanego robotnika ${ }^{72}$.

Problem powyższy został następnie poruszony podczas obrad Rady Miejskiej, która podjęła stosowną uchwałę ${ }^{73}$.

Ostatecznie zagadnienie stawek otrzymywanych przez ławników zostało uregulowane Ustawa z dnia 18 marca 1921 r. o wynagrodzeniu tawników sąów pokoju ${ }^{74}$, która obowiązywała tylko na ziemiach byłego zaboru rosyjskiego ${ }^{75}$. Zgodnie $\mathrm{z}$ art. 1 tego aktu prawnego ławnicy mieli otrzymywać wynagrodzenie stanowiące wyłącznie odszkodowanie za utracony czas i poniesione koszty. Jego wysokość nie została sprecyzowana w ustawie, ale miała być ustalona przez ministra sprawiedliwości w porozumieniu z ministrem skarbu. Dopuszczalne było także określenie różnej wysokości stawek w stosunku do poszczególnych miejscowości.

Ponadto ustawodawca przyznał ławnikom dietę w wysokości 20 marek za każdy dzień posiedzenia oraz zwrot kosztów podróży w przypadku, gdyby czynności urzędowe odbywały się poza siedzibą sądu w odległości większej niż 15 kilometrów od miejsca zamieszkania ławnika. Dieta miała przysługiwać, o ile wyjazd trwał co najmniej pięć godzin. Koszty podróży miały być ustalane według cen biletów kolejowych w drugiej klasie $^{76}$.

Wysokość wynagrodzenia została ustalona mocą Rozporządzenia Ministra Sprawiedliwości z dnia 31 maja 1921 r. o wynagrodzeniu ławników sądów pokoju i wynosiła 100 marek polskich za każdy dzień posiedzenia. Ponadto ławnicy zamieszkali w odległości większej niż 5 kilometrów od siedziby sądu mogli składać wnioski o zwrot kosztów podróży, w wysokości ceny biletu kolejowego w drugiej klasie (w obie strony). W przypadku zaś braku takiej komunikacji - w wysokości 15 marek od każdego rozpoczętego kilometra ${ }^{77}$.

Następnie wysokość stawki dziennej została podwyższona mocą Rozporządzenia Ministra Sprawiedliwości z dnia 21 marca 1923 r. o wynagrodzeniu tawników sądów pokoju, w okręgach sądów apelacyjnych w Warszawie i Lublinie. §1 tego aktu określił wysokość stawki dziennej na 3000 marek, jednocześnie zastrzegając, że wysokość ta będzie się zmieniać proporcjonalnie do diety funkcjonariuszy państwowych ${ }^{78}$.

\footnotetext{
72 Wyciąg z protokołu posiedzenia Komisji do Spraw Ogólnych z 17 I 1921 r.; ibid., 154.

73 Wyciąg z posiedzenia Rady Miejskiej w Łodzi z 20 I 1921 r.; ibid., 158-159.

74 Dz. U. 1921 nr 30, poz. 173.

75 Art. 4 ustawy.

76 Art. 2 ustawy.

77 Dz. U. $1921 \mathrm{nr}$ 47, poz. 295.

78 Dz. U. 1923 nr 31, poz. 197.
} 


\section{Problem związany z ujawnieniem listy ławników}

W latach 1920-1922 rozgorzał konflikt między Radą Miejską w Łodzi a prezesem tutejszego Sądu Okręgowego. Był on związany z nieujawnianiem przez tego ostatniego listy powołanych ławników.

Rozpoczął się od prośby Rady Miejskiej, która w piśmie z 11 XI 1920 r. zwróciła się do prezesa SOwŁ z wnioskiem o przesłanie listy ławników powołanych do tego sądu spośród kandydatów wskazanych przez Radę uchwałą z 7 IX 1920 r. ${ }^{79}$ Prośbę ponowiła 9 XII tego samego roku ${ }^{80}$ i 3 I roku następnego ${ }^{81}$. W odpowiedzi prezes twierdził, że nie dostał dwóch pierwszych pism ${ }^{82}$.

Kolejna odezwa Rady Miejskiej w tej sprawie została wydana 16 III 1921 r. ${ }^{83}$ Prezes SOwŁ udzielił wymijającej odpowiedzi 24 III. Pisał: „Na skutek odezwy z dnia 16 b.m. nr 146/21, zawiadamiam, że odezwa Rady Miejskiej z dnia 11 listopada 1920 r. [...] o nadesłanie listy wybranych przez Radę kandydatów na ławników dla Sądu Okręgowego dotychczas nie nadeszła" ${ }^{44}$.

Następne pismo Rady Miejskiej z 15 XII 1921 r. do prezesa SOwŁ Władysława Augustynowicza było już sporządzone w ostrzejszym tonie:

W wykonaniu postanowienia Rady Miejskiej podajemy do wiadomości Pana następującą uchwałę, powziętą w dniu wczorajszym: „W związku z powoływaniem ławników przez Pana Prezesa Sądu Okręgowego w Łodzi Rada Miejska, przedstawiając listę kandydatów na ławników, zwróciła się w swoim czasie do Sądu Okręgowego z prośbą o zakomunikowanie, którzy z podanych kandydatów zatwierdzeni zostali w charakterze ławników, względnie zastępców. Pismo odnośne, jak również cztery następne w tej sprawie do Sądu Okręgowego przesłane pozostały dotychczas bez odpowiedzi. Dopatrując się w tem lekceważenia organizacji samorządowej, Rada Miejska postanawia przesłać bezpośrednio na ręce Pana Prezesa Sądu Okręgowego w Łodzi powyższą enuncjację z zaznaczeniem, że kancelaria sądowa winna była przesłać Radzie Miejskiej omawianą listę kandydatów, ewentualnie wyjaśnić, jakie przepisy prawne stoją na przeszkodzie ujawnieniu listy kandydatów"85.

Dokument ten budzi jednak wątpliwości w kwestii organu, do którego ławnicy mieli być powołani. Wskazano w nim, że chodzi o ławników Sądu Okręgowego. Tymczasem zgodnie z „Przepisami tymczasowymi o urządzeniu sądownictwa w Królestwie Polskiem” z 1917 r. do uprawnień prezesów sądów okręgowych nie należało mianowanie ławników do sądu tego szczebla. Uprawnienie to przysługiwało prezesom sądów apelacyjnych.

Prezes ponownie udzielił wymijającej odpowiedzi 31 XII 1921 r., wskazując, że „W dzienniku prezydialnym papierów wchodzących jest zapisana jedna tylko odezwa Rady Miejskiej z dnia 15 marca r.b. nr 146/21, na którą została udzielona odpowiedź 24 marca r.b. Nr 2300/21" $"$.

79 „Prosimy o podanie nam nazwisk tych spośród wybranych przez Radę Miejską na zasadzie uchwały z dnia 7. września r.b. kandydatów, którzy powołani zostali na ławników Sądu Okręgowego"; Odezwa nr 1586/20 z 11 XI 1920 r.; APŁ, AMŁ 13105, 174.

${ }^{80}$ Odezwa z 9 XII 1920 r.; ibid., 175.

81 Odezwa z 3 I 1921 r.; ibid., 176.

${ }^{82}$ Pismo nr 119/21 z 7 I 1921 r.; ibid., 177.

${ }^{83}$ Odezwa nr 146/21 z 16 III 1921 r.; ibid., 180.

${ }^{84}$ Odezwa nr 2360/21 z 14 III 1921 r.; ibid., 181.

${ }^{85}$ Odpis pisma z 15 XII 1921 r.; ibid., 262.

86 Odezwa z 31 XII 1921 r.; APŁ, AMŁ 13105, 277.

Artykuły - Articles 
W związku z tym Rada Miejska jeszcze 8 IV 1922 r. w piśmie skierowanym do magistratu wskazywała, że wciąż nie otrzymała listy, i prosiła magistrat o interwencję ${ }^{87}$. W aktach archiwalnych brak jakichkolwiek śladów dalszej dyskusji. Najwyraźniej więc sprawa nie została rozwiązana.

\section{Zakończenie}

Powoływanie ławników do łódzkich sądów napotykało pewne problemy. Przede wszystkim były one związane ze zwiększaniem się liczby spraw, które były rozstrzygane w składach ławniczych. $Z$ tego wynikało wzrastające zapotrzebowanie na ich usługi. Tymczasem wynagrodzenie otrzymywane przez ławników było niewielkie i w związku z tym część mianowanych osób niechętnie realizowała powierzone im obowiązki. Problem ten został częściowo rozwiązany Ustawa z dnia 18 marca 1921 r. o wynagrodzeniu ławników sądów pokoju i wydawanymi do niej rozporządzeniami wykonawczymi. Sytuację z pewnością poprawiło również wydłużenie kadencji ławników do trzech lat i przyjęcie reguły, zgodnie z którą ustępujący ławnik miał pełnić swoją funkcję do czasu powołania następcy.

Dodatkowo należy zauważyć, że Rada Miejska w Łodzi coraz sprawniej realizowała procedurę wyłaniania kandydatów, w związku z tym opóźnienia w zakresie powoływania ławników były coraz mniejsze.

Zasady organizacji i funkcjonowania sądów pokoju oraz sądów okręgowych, w tym przepisy dotyczące ławników, przyjęte w 1917 r., w dużej mierze obowiązywały aż do 31 XII 1928 r. Następnego dnia, czyli 1 stycznia 1929 r., weszły w życie przepisy rozporządzenia Prezydenta Rzeczypospolitej z dnia 6 lutego 1928 r. Prawo o ustroju sądów powszechnych ${ }^{88}$, które ostatecznie ujednoliciły organizację sądownictwa powszechnego.

\section{Bibliografia}

\section{Źródła archiwalne}

Archiwum Państwowe w Łodzi, Akta miasta Łodzi. Rada Miejska, sygn. 13104 Sprawa wyboru ławników (1917-1918), mikrofilm L-10980. [APŁ, AMŁ 13104].

Archiwum Państwowe w Łodzi, Akta miasta Łodzi. Rada Miejska, sygn. 13105 Sprawa wyboru ławników dla Sądu Okręgowego i Sądów Pokoju (1919-1927), mikrofilm L-10981. [APŁ, AMŁ 13105].

87 „Jednocześnie prosimy o zaznaczenie w piśmie do Prezesa Sądu, że pomimo przyrzeczenia jego (pismo Pr.10275/21 z dn. 31 grudnia 1921 r.) do dzisiejszego dnia nie została nam nadesłana lista mianowanych na okres 3-letni ławników dla sądów pokoju w Łodzi”; Pismo nr dz. 406/22 z 8 IV 1922 r.; ibid., 283.

${ }^{88}$ Art. 299 rozporządzenia Prezydenta Rzeczypospolitej z dnia 6 lutego 1928 r.: „Rozporządzenie niniejsze wchodzi w życie z dniem 1 stycznia 1929 r.”. Dz.U. 1928 nr 12 poz. 93. Materniak-Pawłowska, „Sądy Królewsko-Polskie”, 106. 


\section{Źródła prawne}

Przepisy przechodnie do ustawy postępowania cywilnego (Dziennik Urzędowy Departamentu Sprawiedliwości Tymczasowej Rady Stanu Królestwa Polskiego z 1917 r. nr 1).

Przepisy przechodnie do ustawy postępowania karnego (Dziennik Urzędowy Departamentu Sprawiedliwości Tymczasowej Rady Stanu Królestwa Polskiego z 1917 r. nr 1).

Przepisy tymczasowe o urządzeniu sądownictwa w Królestwie Polskim (Dziennik Urzędowy Departamentu Sprawiedliwości Tymczasowej Rady Stanu Królestwa Polskiego z 1917 r. nr 1).

Rozporzadzenie Ministra Sprawiedliwości z dnia 31 maja 1921 r. o wynagrodzeniu ławników sąów pokoju (Dz.U. z 1921 r. nr 47, poz. 295).

Rozporzadzenie Ministra Sprawiedliwości z dnia 21 marca 1923 r. o wynagrodzeniu ławników sąów pokoju, w okręgach sąów apelacyjnych w Warszawie i Lublinie (Dz.U. z 1923 r. nr 31, poz. 197).

Tymczasowa instrukcja ogólna dla sądów Królestwa Polskiego (Dziennik Urzędowy Departamentu Sprawiedliwości Tymczasowej Rady Stanu Królestwa Polskiego z 1917 r. nr 2).

Ustawa z dnia 18 marca 1921 r. o wynagrodzeniu ławników sąów pokoju (Dz.U. z 1921 r. nr 30, poz. 173).

Ustawa z dnia 18 marca $1921 \mathrm{r}$. w przedmiocie niektórych zmian $w$ przepisach tymczasowych o urzadzeniu sądownictwa w b. Królestwie Polskiem (Dz.U. z 1921 r. nr 30, poz. 172).

\section{Opracowania}

Gołąb, Stanisław. Organizacja sądów powszechnych opracowana systematycznie z uwzględnieniem rozwoju historycznego, sądownictwa szczególnego oraz ustroju adwokatury, Prokuratorii Generalnej i notariatu, Kraków: nakł. autora [s.n.], 1938.

Jastrzębski, Robert. „O stu latach Sądu Najwyższego (1917-2017)”. Palestra 62, nr 4 (2017): $70-6$.

Materniak-Pawłowska, Małgorzata. „Departament Sprawiedliwości Tymczasowej Rady Stanu i początki Ministerstwa Sprawiedliwości (luty 1917 - październik 1918)”. Czasopismo Prawno-Historyczne 58, z. 2 (2006): 249-72.

Materniak-Pawłowska, Małgorzata. „Sądy Królewsko-Polskie (1917-1918)”. Czasopismo Prawno-Historyczne 59, z. 1 (2007): 87-109.

Materniak-Pawłowska, Małgorzata. „Struktura polskich sądów powszechnych w latach 19171928". Czasopismo Prawno-Historyczne 53, z. 1 (2001): 275-84.

Materniak-Pawłowska, Małgorzata. Ustrój sądownictwa powszechnego w II Rzeczypospolitej. Poznań: Wydział Prawa i Administracji Uniwersytetu im. Adama Mickiewicza, 2003.

Materniak-Pawłowska, Małgorzata. „Zawód sędziego w Polsce w latach 1918-1939”. Czasopismo Prawno-Historyczne 63, z. 1 (2011): 63-110.

Płaza, Stanisław. Historia prawa w Polsce na tle porównawczym. Cz. III: Okres międzywojenny. Kraków: Księgarnia Akademicka, 1998.

Ryszka, Franciszek, red.. Historia państwa i prawa Polski 1918-1939. Cz. II. Warszawa: Państwowe Wydawnictwo Naukowe, 1962. 
Wiśniewska, Dorota. „Sądownictwo powszechne w pierwszych latach niepodległości”. W Niepodległa. Rozważania prawno-ustrojowe w 100. rocznicę odrodzenia suwerennego państwa polskiego, red. Anna Michalak i Aldona Domańska, 175-86. Łódź: Wydawnictwo Uniwersytetu Łódzkiego, 2018. 